\title{
Nutritional composition of the pulp of Pajurá (Couepia bracteosa Benth.), an underutilized fruit from the Amazon
} \author{
Agnaldo Tremea ${ }^{4}$, Jesus Nazareno S Souza ${ }^{5}$ and José Guilherme S Maia ${ }^{3 *}$ \\ ${ }^{1}$ Programa de Pós-Graduação em Biociências, Universidade Federal do Oeste do Pará, 68035-110 Santarém, PA, Brazil \\ ${ }^{2}$ Laboratório de Bioprospecção e Biologia Experimental, Universidade Federal do Oeste do Pará, 68035-110 Santarém, PA, Brazil \\ ${ }^{3}$ Programa de Pós-Graduação em Química, Universidade Federal do Pará, 66075-900 Belém, PA, Brazil \\ ${ }^{4}$ Instituto Nacional de Colonização e Reforma Agrária, 68040-060 Santarém, PA, Brasil \\ ${ }^{5}$ Faculdade de Engenharia de Alimentos, Universidade Federal do Pará, 66095-780 Belém, PA, Brasil
}

Lais Tatiele Massing ${ }^{1}$, Rosa Helena V Mourão ${ }^{1,2}$, Leoneide Érica M Bouillet ${ }^{2}$, Regiane Sablina A Bernardes ${ }^{2}$, Eloisa Helena A Andrade ${ }^{3}$,

\begin{abstract}
Couepia bracteosa Benth. (Chrysobalanaceae), known as pajurá, is a native fruit that occurs spontaneously in the Amazon region, with an exotic flavor and low commercial exploitation. This study describes the biochemical and nutritional composition and the antioxidant and hemagglutinating activities for the natural and lyophilized Pajurá pulps. Fruits are characterized by their high percentage of sugar and total fiber content (34.7\%), significant antioxidant capacity (DPPH, 53.42\%; $\beta$-carotene/linoleic acid, $69.85 \%)$ and the absence of haemagglutinating activity. The percentile of vitamin C (22.42 mg/100 g), total phenolic compounds (124.53 $\mathrm{mgGAE} / 100 \mathrm{~g})$ and total carotenoids $(2898.76 \mu \mathrm{g} / 100 \mathrm{~g})$ were also evaluated. Primary fatty acids found in its lipid fraction were oleic (30.2\%), lauric (18.1\%), palmitic (16.1\%), and myristic (11.1\%) acids. Also, the pulp presented a pleasant aroma with a high content of $(E)-\beta-O c i m e n e(49.2 \%)$. It is presumed that results can contribute to a better fruit utilization, which may have potential application as a novel functional food.
\end{abstract}

\section{Introduction}

In addition to their organoleptic characteristics, many fruits have attracted the attention of the scientific research and consumers due to the presence of minerals, vitamins, bioactive compounds, and fibers. Fruits with these properties can contribute to the risk reduction of chronic non-communicable diseases, such as cancer and cardiovascular diseases $[1,2]$.

In Brazil, it is estimated that $44 \%$ of the native fruits are located in the Amazon region, considered a valuable natural reserve of food and medicinal plants worldwide. However, most of the native fruits from the Amazon are wild or cultivated only for the local markets, not having yet defined their economic potential. This fact is due to the absence of studies related to the conditions of crop growth, lack of data on the composition of the fruits, their nutritional value, lack of knowledge about the presence of bioactive compounds and the possibilities of commercialization $[2,3]$.

Couepia bracteosa Benth. (Chrysobalanaceae), popularly known as Pajurá, is a fruitful species of the Brazilian Amazon, occurring in the Pará, Amazonas, and Roraima states. The tree is between 12 to 25 meters long, produces globular fruit type drupe of brown epicarp and yellowish pulp, thick and granular, with a pleasant aroma and sweet taste. The harvest occurs between November and May, and the fruit is consumed regionally in nature or as an ingredient in desserts [4]. Previously, the proximate composition, fatty acid and mineral content, and identification of some phenolic and carotenoid compounds were analyzed and determined in the pulp of C. bracteosa [5-7]. Also, there are records of bioactive compounds identified in other Couepia species, such as the conjugated fatty acids in the seed oils of $C$. edulis and C. longipendula $[8,9]$, phenolic compounds in C. paraensis and C. ulei $[10,11]$, and an oleanane triterpenoid from C. polyandra with anticancer activity [12].

Although the consumption of Amazonian fruits has a regional predominance, these fruits present great possibilities for their use in agroindustry. Also, scientific research that seeks to identify functional properties in fruits also promotes their commercial value and, as a consequence, can benefit family farming and contribute to the sustainable development of the region. The most significant challenge for the exploration and commercialization of new fruit species, particularly in the most distant and hard-to-reach areas is the preservation of their organoleptic characteristics and their nutritional value, given the prospect of high perishability during transport [13].

Nowadays, the post-harvest loss of fruit in Brazil reaches 30\%. These losses stem from the choice of inappropriate cultivars, improper postharvest techniques, poor transport conditions and inadequate storage for the products. On the other hand, there is a growing interest in processed fruits, both domestically and abroad the country, due to the demand for healthy foods that are convenient and ready for

Correspondence to: José Guilherme S. Maia, Programa de Pós-Graduação em Química, Universidade Federal do Pará, 66075-900 Belém, PA, Brazil, E-mail: gmaia@ufpa.br

Key words: Pajurá, Couepia bracteosa, Chrysobalanaceae, Biochemical and nutritional composition, fibers, funcional food

Received: March 08, 2018; Accepted: March 27, 2018; Published: March 30, 2018 
consumption, with a long shelf time and to providing seasonal fruits throughout the year. In this context, the dehydration process becomes a real option to maintain the quality of the fruits, both for direct consumption and in the form of ingredients for new preparations. As the fruits are rich in vitamins and antioxidants, among other heat-sensitive nutrients, when processed by conventional dehydration methods may have reduced their nutritional value and organoleptic characteristics. Thus, the lyophilization process is considered one of the most adequate to maintain the essential aspects of the fruits [14].

The present work aimed to characterize the biochemical and nutritional composition of the natural and lyophilized pulps of $C$. bracteosa, including their physicochemical and analytical aspects, the centesimal composition, antioxidant properties, total carotenoids and phenolic compounds, and the hemagglutinating activity. This study was carried out with the intention of identifying characteristics and benefits for the human consumption of Pajurá, as well as to detect other functional attributes for the fruit.

\section{Materials and methods}

\section{Drugs and reagents}

The reagents Folin-Ciocalteu, Trolox (6-hydroxy-2,5,7,8tetramethylchroman-2-carboxylic acid), DPPH (2,2-diphenyl-1picrylhydrazyl), gallic acid, catechin, rutin, linoleic acid, $\beta$-carotene and the methylated fatty acid solution (37 Component Fame Mix) were purchased from Sigma-Aldrich (USA). The LMW GE 17044601 (97 to $14.4 \mathrm{KD}$ ) molecular weight calibration standard (BIO-RAD, Brazil) was used. The other reagents and solvents were all from analytical grade.

\section{Collection data, fruit physical characterization and sample preparation}

The fruits of Couepia bracteosa were collected in the community of Alter do Chão (coordinates 02 $30^{\prime} 18.7^{\prime \prime} \mathrm{S}$ and 54'56'39.4" W), municipality of Santarém, the state of Pará, Brazil, February 2016. Plant samples (aerial parts) were deposited in the herbarium of Universidade Federal do Oeste do Pará (UFOPA), under the number HSTM 000094. After cleaning and sanitization, ten fruits were randomly chosen for the following biometric analyses: (1) transverse and longitudinal diameter of the fruit and seed, measured with a standard caliper; (2) individual weighing of the whole fruit, pulp, seed, and bark, with the aid of a digital scale. The fresh and lyophilized pulp were stored at $-18^{\circ} \mathrm{C}$, for further analysis.

\section{Physical-chemical characterization of the pulp}

Reducing sugars of the natural and lyophilized pulps were determined by titration using a Fehling's solution, and the values were expressed as percentages of reducing sugars for $100 \mathrm{~g}$ of pulp. Total Soluble Solids (TSS) were quantified by refractometry and the result shown in Brix degree [15]. All the tests were performed in triplicate. The granulometric analysis, water solubility index (WSI) and water absorption index (WAI) were determined to identify possible technological properties of the material resulting from the process of pulp lyophilization. The granulometry was measured in six different sieves, with openings between 75 and $600 \mu \mathrm{m}$ [16]. The WSI and WAI values were obtained by diluting the sample in distilled water (1:10). The mixture was stirred and centrifuged $(30 \mathrm{~min})$ and the supernatant transferred to an oven $\left(105^{\circ} \mathrm{C}, 4 \mathrm{~h}\right)$. Then, after cooling and weighing the WSI value was determined. The resulted precipitate was again considered, and the difference between the weight dry and weight wet was calculated for the determination of the WAI value.

\section{Centesimal composition of the pulp}

Moisture, ash and protein contents (g/100 g) were determined according to the recommendations of Instituto Adolfo Lutz [15]. Total nitrogen was converted to protein multiplying its value by the conversion factor of 6.25. Molar weight of soluble protein was obtained by SDS-PAGE electrophoresis [17]. Lipid content was quantified by the method of Bligh and Dyer, according to Instituto Adolfo Lutz [15]. Total fibers (soluble and insoluble) were calculated by the method of Cunniff and Association of Official Analytical Chemists [18]. The carbohydrate content $(\mathrm{g} / 100 \mathrm{~g})$ was determined by exclusion in the analysis of the centesimal composition. The total energy value was estimated by multiplying the conversion factor of $16.8 \mathrm{~kJ}$ per $\mathrm{g}$ for carbohydrates and proteins, and $37.8 \mathrm{~kJ}$ per $\mathrm{g}$ for lipids. Vitamin $\mathrm{C}$ was quantified by Tillmans method, according to Instituto Adolfo Lutz [15].

\section{Fatty acid analysis}

Lipid fraction from the pulp (100 g) was extracted in a Soxhlet apparatus using hexane and acetone as solvents. The lipid esterification was performed subsequently, according to Khan and Scheinmann [19]. The fatty acid methyl esters identification was performed by GCMS, using QP-2010-Plus equipment (Shimadzu Corporation, Tokyo, Japan) and a silica capillary column (Rtx-5ms, $30 \mathrm{~m} \times 0.25 \mathrm{~mm} \times 0.25$ $\mu \mathrm{m})$, with the aid of the MS Solution software and standard libraries $[20,21]$. The conditions of analysis were: injector temperature $250^{\circ} \mathrm{C}$; oven temperature programming starting in $100^{\circ} \mathrm{C}(5 \mathrm{~min})$ and then with a gradient of $4^{\circ} \mathrm{C} / \mathrm{min}$ up to $260^{\circ} \mathrm{C}(20 \mathrm{~min})$; carrier gas, helium $(1.2 \mathrm{ml} / \mathrm{min})$; split-type injection of $1.0 \mu \mathrm{l}$ of the sample; ionization by electron impact, $70 \mathrm{EV}$; temperatures of ion source and transfer line in $220^{\circ} \mathrm{C}$ and $250^{\circ} \mathrm{C}$, respectively. The constituents were identified by comparison of their retention times and mass spectra with those of standards fatty acids existing in the libraries.

\section{Extraction and analysis of the volatile concentrates}

The natural and lyophilized pulps (5 g, each) were subjected to extraction $(2 \mathrm{~h})$ with a simultaneous distillation-extraction microsystem to obtain their volatile concentrates, using a Likens \& Nickerson-type apparatus [22] and pentane as the solvent (4 ml). The analysis of the volatile concentrates was carried out by GC-MS under working conditions already mentioned, except the oven temperature programming which was $60-240^{\circ} \mathrm{C}\left(3^{\circ} \mathrm{C} / \mathrm{min}\right)$. Mass spectra were obtained by automatic scanning $(0.3 \mathrm{~s}$, each), with mass fragments varying from 35 to $400 \mathrm{~m} / \mathrm{z}$. Retention index was calculated for all volatile components using a homologous series of alkanes $\left(\mathrm{C}_{8}-\mathrm{C}_{20}\right.$, Sigma-Aldrich), according to van den Dool \& Kratz [23]. Constituents were identified by comparing their retention indices and mass spectra libraries (molecular mass and fragmentation pattern), as well as consulting the mass spectra literature.

\section{Detection of lectins with hemagglutinating activity}

The detection of lectins with hemagglutinating activity in the Pajurá pulp was performed using microtiter plates [24]. The natural and lyophilized pulps, after serial dilution in sodium phosphate buffer $(1: 2,1: 4$ and $1: 8, \mathrm{pH} 7.4)$, were incubated with a mouse erythrocyte suspension $(4 \%, 50 \mu \mathrm{l})$, at room temperature. The visual and magnifying glass readings were performed to analyze the erythrocytes hemagglutination, after 60 and $90 \mathrm{~min}$. Wells containing only the sodium phosphate buffer and the erythrocyte suspension was used as the control. 


\section{Preparation of extracts to determine antioxidant capacity, total phenolics total and carotenoids}

The lipophilic extract was obtained according to Rodriguez-Amaya [25]. Briefly, the sample (6g) was macerated with cooled acetone (50 $\mathrm{ml})$. The resulting extract was filtered and transferred to a separatory flask where petroleum ether $(40 \mathrm{ml}$, triplicate) and distilled water $(150 \mathrm{ml})$ were added. After phase separation, water and acetone were discarded. The petroleum ether phase was filtered on anhydrous sodium sulfate and transferred to a volumetric flask, supplemented with an additional part of the solvent. The hydrophilic extract was prepared with a solution of acetone (70.0\%), distilled water (29.5\%) and acetic acid (0.5\%) [3]. The ratio between the sample and solution was 1:1 for natural pulp and 2:8 for lyophilized pulp. The mixture was homogenized in a shaker incubator $(80 \mathrm{rpm}, 1 \mathrm{~h})$, at room temperature and then filtered. The process was repeated two times. Ethanolic extracts for the natural and lyophilized pulps were prepared at the proportion of 1:2 and 1:10 (pulp:ethanol), respectively. The mixtures were stirred $(1 \mathrm{~h})$, centrifuged $(5000 \mathrm{rpm})$ at the temperature of $15^{\circ} \mathrm{C}(10 \mathrm{~min})$ and filtered.

\section{Determination of total carotenoids}

Carotenoids were quantified according to Rodriguez-Amaya [25] based on the lipophilic extracts of the pulps and the absorbance reading at $450 \mathrm{~nm}$. The results were calculated by the absorbance coefficient of petroleum ether and expressed in micrograms of $\beta$-carotene equivalents per $100 \mathrm{~g}$ of pulp.

\section{Determination of total phenolic compounds}

The content of total phenolic compounds was determined by the Folin-Ciocalteu colorimetric method [26]. An aliquot of hydrophilic extract $(500 \mu \mathrm{l})$ was added to a sodium carbonate solution $(1250 \mu \mathrm{l}$, $75 \mathrm{~g} / \mathrm{l})$ and the Folin-Ciocalteu solution $(250 \mu \mathrm{l}, 1 \mathrm{~N})$. The mixture was homogenized and incubated sheltered from the light $(30 \mathrm{~min})$ and then the reading performed at $735 \mathrm{~nm}$. A calibration curve for the gallic acid was constructed, and the results were expressed in milligrams of gallic acid equivalents per $100 \mathrm{~g}$ of pulp.

\section{Antioxidant activity by DPPH (2,2-diphenyl-1-picryl- hydrazyl) assay}

The DPPH antioxidant activity of ethanolic extract of the pulps was determined by the method of Miliauskas and colleagues [27]. Aliquots of the extracts in natural $(75 \mu \mathrm{l}$, concentration from 0.14 to $4.72 \mathrm{mg} / \mathrm{ml}$, on dry basis) and lyophilized (75 $\mu \mathrm{l}$, concentration from 0.069 to $2.24 \mathrm{mg} / \mathrm{ml}$, on dry basis) were added to the DPPH methanolic solution $(2925 \mu \mathrm{l}, 60 \mu \mathrm{M})$. The absorbance at $517 \mathrm{~nm}$ of the solutions was measured after 5, 15, 30, 45, 60, 75 and 90 min of reaction. Trolox ( 1 to $5 \mu \mathrm{g} / \mathrm{ml}$, in ethanol) was used as the standard, and the results were expressed in inhibition concentration $\left(\mathrm{IC}_{50}, \mathrm{mg} / \mathrm{ml}\right)$ and inhibition percent (I\%).

\section{Antioxidant activity by $\beta$-carotene and linoleic acid assay}

A reaction mixture was prepared with linoleic acid $(20 \mu \mathrm{l})$, tween $40(265 \mu \mathrm{l}), \beta$-carotene solution $(1.0 \mathrm{ml}, 0.2 \mathrm{mg} / \mathrm{ml}$ in chloroform), and water $(50 \mathrm{ml})$, previously saturated with oxygen $(30 \mathrm{~min})$. Then, the orange-yellow color mixture was vigorously stirred. The test was performed by the addition of an aliquot of the reactive solution $(2.5 \mathrm{ml})$ to the ethanolic extracts $(200 \mu \mathrm{l}, 6 \mathrm{mg} / \mathrm{ml}$ of the natural and lyophilized pulps, on dry basis) and incubated in a water bath $\left(15 \mathrm{~min}, 50^{\circ} \mathrm{C}\right)$. The absorbance reading at $470 \mathrm{~nm}$ was monitored at the zero time, every $15 \mathrm{~min}$, for $2 \mathrm{~h}$. The same procedure was performed for the control (ethanol) and the standard (Trolox in ethanol, $1 \mathrm{mg} / \mathrm{ml}$ ). The results were expressed as inhibition percent (I\%) [28].

\section{Statistical analysis}

All assays were performed in triplicate, and the results expressed as the mean \pm standard deviation and subjected to analysis of variance (ANOVA), using the Assistat 7.7 beta software.

\section{Results and discussion}

\section{Fruit biometric characterization}

Biometric features of the C. bracteosa fruit are described in Table 1. The fruits are oviform with a mean longitudinal length of $9.5 \pm 1.1$ $\mathrm{cm}$ and a cross-section of $6.75 \pm 0.1 \mathrm{~cm}$, with an average weight of $257.8 \pm 46.5 \mathrm{~g}$ (Figure 1). In percentage terms, the pulp, bark, and seed have mean values of $51.3 \%, 22.6 \%$, and $26.1 \%$, respectively. These results are very close to that early described $[4,29]$. By comparison, although the fruits have been collected in distinct areas of the Amazon (Pará and Amazonas states), it is observed that there are similar physical characteristics, which presupposes a homogeneity for the species. The analyzed samples showed a medium yield profile for this fruit pulp, contributing to its probable use as a new source of food and with significant nutritional value. Other Amazon traditional fruits such as açaí (Euterpe oleracea Mart.), bacuri (Platonia insignis Mart.) and pequiá (Caryocar villosum Pers.), classified as low yield fruit pulps, have good acceptance and are considered of significant economic value [29].

\section{Centesimal composition of pulp}

The centesimal composition and some physicochemical characteristics of the C. bracteosa pulp is shown in Table 2. Composition analysis of the natural and lyophilized pulps, on a dry basis, has revealed that this fruit is a source of vitamin C, minerals (ashes), proteins, lipids and mainly carbohydrates $(60.39 \pm 0.08 \mathrm{~g} / 100 \mathrm{~g}$ and $59.79 \pm 0.46 \mathrm{~g} / 100$ g, respectively), of which 30 to $40 \%$ are classified as reducing sugars (monosaccharides). The reducing sugar content in the natural and lyophilized pulps $(41.58 \pm 3.52 \%$ and $34.1 \pm 2.45 \%)$, as well as the total

Table 1. Biometric features for the fruit of Couepia bracteosa
\begin{tabular}{|c|c|}
\hline Biometric features & Description \\
\hline Fruit, longitudinal diameter $(\mathrm{cm})$ & $9.5 \pm 1.1$ \\
\hline Fruit, transverse diameter $(\mathrm{cm})$ & $6.76 \pm 0.1$ \\
\hline Seed, longitudinal diameter $(\mathrm{cm})$ & $6.43 \pm 0.6$ \\
\hline Seed, transverse diameter $(\mathrm{cm})$ & $4.21 \pm 0.2$ \\
\hline Whole fruit (g, \%) & $257.8 \pm 46.5(100 \%)$ \\
\hline Thick bark, fruit (g, \%) & $58.35 \pm 11.0(22.6 \%)$ \\
\hline Seed, fruit (g, \%) & $67.20 \pm 11.6(26.1 \%)$ \\
\hline Pulp, fruit (g, \%) & $132.25 \pm 28.5(51.3 \%)$ \\
\hline
\end{tabular}

Results expressed as a mean \pm standard deviation $(\mathrm{n}=10)$.

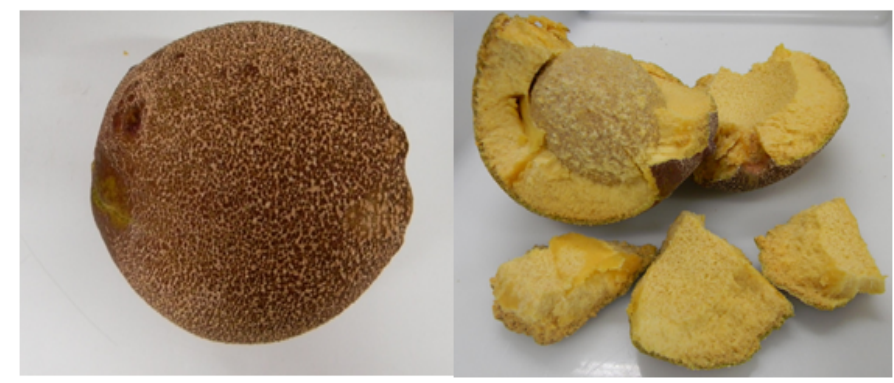

Figure 1. Whole fruit, pulp and seed of Pajurá (Couepia bracteosa Benth). 
Table 2. Centesimal composition and physical-chemical characteristics of the natural and lyophilized pulps of Couepia bracteosa, on a dry basis

\begin{tabular}{|c|c|c|}
\hline Description & Natural Pulp & Lyophilized pulp \\
\hline Moisture (\%) & $62.21 \pm 0.44^{\mathrm{b}}$ & $10.35 \pm 0.13^{\mathrm{a}}$ \\
\hline Ash (\%, g/100g) & $1.98 \pm 0.14^{\mathrm{a}}$ & $1.98 \pm 0.14^{\mathrm{a}}$ \\
\hline Proteins (\%, g/100g) & $2.68 \pm 0.05^{\mathrm{a}}$ & $2.74 \pm 0.25$ \\
\hline Lipids (5, g/100g) & $0.28 \pm 0.01^{\mathrm{b}}$ & $0.73 \pm 0.03^{\mathrm{a}}$ \\
\hline Carbohydrates $(\%, \mathrm{~g} / 100 \mathrm{~g})$ & $60.39 \pm 0.08^{\mathrm{a}}$ & $59.79 \pm 0.46^{\mathrm{a}}$ \\
\hline Soluble fibers $(\%, \mathrm{~g} / 100 \mathrm{~g})$ & $0.50 \pm 0.0^{\mathrm{b}}$ & $0.50 \pm 0^{\mathrm{a}}$ \\
\hline Insoluble fibers $(\%, \mathrm{~g} / 100 \mathrm{~g})$ & $34.17 \pm 0^{\mathrm{b}}$ & $34.2 \pm 0^{\mathrm{a}}$ \\
\hline Total food fibers $(\%, \mathrm{~g} / 100 \mathrm{~g})$ & $34.67 \pm 0^{\mathrm{b}}$ & $34.7 \pm 0^{\mathrm{a}}$ \\
\hline Total caloric value $(\mathrm{kJ} / 100 \mathrm{~g})$ & $1070.21 \pm 2.62^{\mathrm{b}}(254.81 \mathrm{kcal})$ & $1080.28 \pm 1.56^{\mathrm{a}}(257.21 \mathrm{kcal})$ \\
\hline Vitamin C (mg/100g) & $18.42 \pm 0.0^{\mathrm{a}}$ & $22.42 \pm 1.49^{\mathrm{a}}$ \\
\hline Total soluble solids (TSS, \%) & $31.76 \pm 0.0^{\mathrm{a}}$ & $32.80 \pm 1.39^{\mathrm{a}}$ \\
\hline Reducing sugars (glucose \%) & $41.58 \pm 3.52^{\mathrm{a}}$ & $34.12 \pm 2.45^{\mathrm{a}}$ \\
\hline Water solubility index (\%) & & $3.77 \pm 0.03$ \\
\hline Water absorption index (g/g) & & $2.63 \pm 0.08$ \\
\hline
\end{tabular}

Results expressed as a mean \pm standard deviation $(n=3)$. Means followed by the same letter in the columns do not differ significantly from each other by the Tukey test, at the probability level of $5 \%$.

soluble solids ( $31.76 \pm 0.0 \%$ and $32.80 \pm 1.39 \%$ ), are related to the degree of sweetness of the fruit and demonstrate that the Pajura has palatable attributes to consumption, both in natural and lyophilized pulps. Also, the reducing sugars and other components responsible for aroma and flavor have unique sensory qualities, which may lead to the formulation of differentiated food products and, with these characteristics, could arouse the interest of consumers and the agribusiness.

The granulometric analysis of the pulverized lyophilized pulp has determined the presence of granules with different diameters, where the particles equal to or less than $75 \mu \mathrm{m}$ were predominant $(55.31 \%)$. Particle size influences the rheological characteristics of pulverized foods, such as water absorption, solubility, and intumescence. At the same time, small particles have a more substantial contact surface, which is advantageous when used in a blend of ingredients [30]. The natural pulp presented a water content of $62.2 \%$, which guarantees a higher pulp yield for the fruit in the dehydration process when compared to banana (68.2\%), pineapple (86.3\%) and acerola (Malpighia punicifolia L.) $(90.5 \% \%)[31]$, for example. The evaluation of the water solubility index $(3.77 \pm 0.03 \%)$ and the water absorption index $(2.63 \pm 0.08 \mathrm{~g} / \mathrm{g})$ in the lyophilized pulp allowed to identify the hygroscopic characteristics of the pulp and its quality in technological terms, taking into account the incorporation and development of a new food product. Also, it suggests the choice of suitable packaging for product storage. Thus, the features of the lyophilized Pajurá pulp show great potential for its use as a food ingredient, considering that solubility and granulometry ensure that it is easily incorporated into preparations.

In the natural and lyophilized Pajurá pulps, the values obtained for ash $(1.98 \pm 0.14 \mathrm{~g} / 100 \mathrm{~g})$ and protein $(2.68 \pm 0.05 \mathrm{~g} / 100 \mathrm{~g}$ and $2.74 \pm 0.25$ $\mathrm{g} / 100 \mathrm{~g}$ ) content are within the mean previously observed for several fruits [31]. Electrophoresis analysis showed that the soluble proteins of the fresh and lyophilized pulps have the same molecular weight, which justifies that the dehydration process did not affect the protein structure of the fruit. About vitamin $\mathrm{C}$, it was observed that the natural and lyophilized Pajurá pulps ( $100 \mathrm{~g}$, on a dry basis) could provide about $30 \%$ of the daily intake of vitamin C (men, $75 \mathrm{mg}$; women, $60 \mathrm{mg}$ ) [32]. The results indicate that the vitamin $\mathrm{C}$ present in the fruit pulp was preserved during the lyophilization process. Thus, although the fruit does not offer a high concentration of vitamin $\mathrm{C}$, the consumption of fresh and lyophilized pulp could complement the daily nutritional requirement. The Pajurá pulp is distinguished by the presence of a significant amount of fibers (in natural, $34.67 \mathrm{~g} / 100 \mathrm{~g}$; lyophilized, 34.70 $\mathrm{g} / 100 \mathrm{~g}$ ), which can classify the fruit as a food with substantial functional property, whose value is higher than those recommended in Brazil for other fruits (2.5 g per $100 \mathrm{~g}$, in average) [33]. Between ninety-five fruits described in the Brazilian Food Composition Table [34], only Tucumã (Astrocaryum aculeatum G. Mey.) (12.7 g/100 g), Macaúba (Acrocomia aculeata Jacq.) (13.4 g/100 g), and Pequi (Caryocar brasiliense Camb.) $(19 \mathrm{~g} / 100 \mathrm{~g})$ have a high fiber content as Pajurá [31].

The composition of other natural Pajurá pulp, sampled in the state of Amazonas, Brazil, was previously reported [5]. In that work, moisture, ashes, proteins, and carbohydrates presented values lower than those obtained in the present study, particularly regarding the total calorific value, which was only $712.86 \mathrm{~kJ}$, while the result of the current analysis showed $1070.21 \pm 2.62 \mathrm{~kJ}$. This difference can be attributed to the Pajurá high fiber content, which was not previously determined by those authors. The role of fiber in the gastrointestinal system is still involved and related to its solubility. Soluble fiber is associated with the reduced blood cholesterol levels, the reduced rate of gastric emptying, and absorption of carbohydrates and lipids. Insoluble fiber increases the peristalsis, avoiding constipation. Fibers are fermented by the intestinal flora, producing short chain fatty acids. Some studies have related the consumption of fibers from fruits, vegetables, and cereals, with the risk reduction of colon cancer, for diabetes control, cardiovascular disease and obesity, among other health problems [35].

It should be noted that in the lyophilization process the content of volatile constituents is primarily preserved, which may intensify the flavor of the fruit, a fact of significant interest in establishing a new product based on the fruit pulp. Also, with the dehydration, there is an increase in the energy value of the pulp and, as a consequence, a reduction in the size of the portion of fruit to be consumed or even added to other preparations. At the same time, the lyophilization process reduces the perishability of the fruit, which would result in the fermentation of carbohydrates. This practice will allow a longer shelf life and fruit availability. Thus, the consumption of pajura or the use of lyophilized pulp as ingredients of new preparations may be utilized by the food industry to benefit the health of future consumers. Also, due to the high concentration of fibers, the fruit can be exploited using its extraction for pharmacological purposes or as a food supplement. However, other studies are still needed to identify these fibers and their effect on the human body.

\section{Fatty acids composition}

The fatty acids composition of the Pajurá pulp is shown in Table 3. Eighteen fatty acids were identified, with predominance of oleic acid (C18:1, 30.2\%), lauric acid (C12:0, 18.1\%), palmitic acid (C16:0, 16.1\%), myristic acid (C14:0, 11.1\%), stearic acid (C18:0, 6.4\%) and capric acid (C10:0, 3.7\%). Low contents were observed for the following longchain fatty acids: arachidic (C20:0, 2.2\%), behenic (C22:0, 0.7\%) and lignoceric (C24:0, 0.7\%). Lauric and oleic acids are essential for human nutrition, with proven benefits associated with their consumption. It has antioxidant and anti-inflammatory properties, reducing the risk of cardiovascular diseases [36]. Oleic acid ( $\omega 9)$, one of the most common monounsaturated fatty acids and present in food oils, is the principal constituent of olive oil and has potential action in the primary and secondary prevention of cardiovascular diseases [37]. These results stimulate new research to verify the beneficial effect of Pajurá consumption for prevention and treatment of pathologies associated with eating habits, as is the case of chronic non-communicable diseases. 
Table 3. Composition of fatty acid methyl esters of the lipid fraction of natural pulp of Couepia bracterosa

\begin{tabular}{|c|c|c|c|}
\hline RT & Symbology & Fatty acid, methyl ester & Oil\% \\
\hline 11.408 & C10:0 & Capric acid, methyl ester & 3.7 \\
\hline 15.950 & C11:0 & Undecanoic acid, methyl ester & 0.2 \\
\hline 19.608 & C12:0 & Lauric acid, methyl ester & 18.1 \\
\hline 20.042 & C14:1(9) $\omega 5$ & Myristoleic acid, methyl ester & 0.7 \\
\hline 22.725 & $12-$ Me-C13:0 & Isomyristic acid, methyl ester & 0.2 \\
\hline 26.942 & C14:0 & Myristic acid, methyl ester & 11.1 \\
\hline 30.042 & $\mathrm{C} 15: 0$ & Pentadecanoic acid, methyl ester & 0.4 \\
\hline 33.792 & $\mathrm{C} 16: 1(9) \omega 7$ & Palmitoleicacid, methyl ester & 1.4 \\
\hline 34.050 & $\mathrm{C} 16: 0$ & Palmitic acid, methyl ester & 16.1 \\
\hline 36.025 & $14-\mathrm{Me}-\mathrm{C} 15: 0$ & Isopalmitic acid, methyl ester & 1.2 \\
\hline 36.842 & $\mathrm{C} 17: 0$ & Heptadecanoic acid, methyl ester & 1.5 \\
\hline 38.967 & $\mathrm{C} 18: 2(9,12) \omega 6$ & Linoleic acid, methyl ester & 0.6 \\
\hline 39.733 & $\mathrm{C} 18: 1(9) \omega 9$ & Oleic acid, methyl ester & 30.2 \\
\hline 40.667 & $\mathrm{C} 18: 0$ & Stearic acid, methyl ester & 6.4 \\
\hline 43.075 & $\mathrm{C} 18: 1(11) \omega 7$ & Vaccenic acid, methyl ester & 0.3 \\
\hline 46.008 & $\mathrm{C} 20: 0$ & Arachidic acid, methyl ester & 1.8 \\
\hline 51.400 & $\mathrm{C} 22: 0$ & Behenic acid, methyl ester & 0.7 \\
\hline 56.458 & $\mathrm{C} 24: 0$ & Lignoceric acid, methyl ester & 0.7 \\
\hline Total $(\%)$ & & & 95.3 \\
\hline
\end{tabular}

$\mathrm{RT}=$ retention time (on RTx-5ms capillary column)

\section{Volatile concentrates composition from the pulps}

Constituents identified in the volatile concentrates from the natural and lyophilized pulps are listed in Table 4. Eight components were identified, whose sums correspond to $98.4 \%$ and $100.0 \%$, respectively. The constituents were $(E)$ - $\beta$-ocimene (33.1\% and $49.2 \%),(2 E)$-hexenal (20.8\% and 5.3\%), naphthalene (13.7\% and $14.3 \%)$, 2-ethylhexanol (13.3\% and $18.1 \%)$, hexanal (11.1\% and $6.8 \%)$, eugenol $(3.2 \%$ and 2.7\%), 2.3-hexadienone (3.2\% and $1.8 \%)$ and phenylacetaldehyde (traces and $1.8 \%)$, in decreasing order. $(E)$ - $\beta$-Ocimene, $(2 E)$-hexenal and naphthalene were reported as significant constituents in the fruits of Pitanga (Eugenia uniflora L.) [38], Guava (Psidium guajava L.) [39] and Baguaçu (Talauma ovata A. St.-Hil.) [40]. Volatile constituents are produced during fruit growth and maturation, and their compositions depend on environmental factors, planting conditions, maturation stage, post-harvest period and storage period. Thus, controlled storage conditions may contribute to the formation of the characteristic fruit flavor [41]. The identification of aroma constituents helps to determine the appropriate procedures during the fruit processing, having in mind to guarantee its high quality and to maintain the original flavor in the final product [42].

\section{Detection of lectins and haemagglutinating activity}

Lectins belong to a family of proteins that can bind to specific carbohydrates, reversibly and without altering their structure. Lectins are present in foods of the plant origin such as cereals, legumes, vegetables, and fruits [43]. The analysis of the hemagglutinating activity may indirectly indicate the presence or absence of lectins in Pajurá. Because of their ability to bind to erythrocytes, lectins are employed in research related to biological processes such as cell proliferation, apoptosis, and neoplastic cell metastasis. Studies have shown that the ingestion of some types of lectins may be detrimental to health due to its possible attachment to epithelial cells, with consequent damage to the intestinal epithelium. This fact makes it permeable to toxins, reducing nutrient absorption and possibly triggering inflammatory diseases related to malnutrition [43]. The extracts obtained from the natural and lyophilized pajurá pulps did not present hemagglutinating activity when tested in erythrocytes of mice, suggesting the absence of lectins. However, analysis of the hemagglutinating activity using human erythrocytes and from other animal species becomes necessary to confirm the lack of lectins, since these can react with different blood groups. Taking into account that Pajura is a wild fruit and little used, research proving the safety of its consumption will be necessary to avoid possible nutritional disorders that may harm the health of consumers.

\section{Determination of antioxidant capacity and total carotenoids and phenolic compounds}

The results of the antioxidant capacity assays, which was conducted with the DPPH radical and the $\beta$-carotene/linoleic acid system, as well as for determination of total carotenoids and phenolic compounds, are described in Table 5.

The antioxidants interact with the DPPH through the transfer of electrons or the donation of hydrogen neutralizing its character of free radical [44]. The natural and lyophilized Pajurá pulps, on a dry basis, showed inhibition values (I\%) of $27.20 \pm 0.75 \%$ and $53.42 \pm 3.19 \%$, at the concentration of $4.72 \mathrm{mg} / \mathrm{ml}$ and $2.24 \mathrm{mg} / \mathrm{ml}$, respectively. According the classification proposed by [1], the lyophilized pulp can be considered as having a median antioxidant capacity in comparison to the natural pulp which showed the antioxidant activity with a twice lower value. This difference may be associated with the enzymatic reactions which occur in the natural pulp because it contains a higher content of water and an adequate environment for the oxidation/degradation reactions of the bioactive compounds with antioxidant activity.

In the bleaching oxidation system of $\beta$-carotene, frequently used to evaluate the inhibition of free radicals generated by linoleic acid peroxidation, the Pajurá pulp showed an inhibition value (I\%) of $32.81 \pm 0.19 \%$ of the natural pulp and $69.85 \pm 3.33 \%$ of the lyophilized pulp, on a dry basis and at concentrations of $6 \mathrm{mg} / \mathrm{ml}$. According Rufino and coworkers [28], the natural pulp of Pajurá presented a median antioxidant capacity $(<40 \%)$, while its lyophilized pulp showed a significant antioxidant capacity (between 40 and $70 \%$ ). These results

Table 4. Constituents identified in the volatile concentrates of the natural and lyophilized pulps of Couepia bracteosa

\begin{tabular}{|c|c|c|c|c|}
\hline Constituents & $\mathbf{R I}_{\text {Calc }}$ & $\mathbf{R I}_{\text {Lit }}$ & in natura Pulp (\%) & Lyophilized Pulp (\%) \\
\hline 2,3-Hexadienone & 789 & $781^{\mathrm{a}}$ & 3.2 & 1.8 \\
\hline Hexanal & 800 & $801^{\mathrm{b}}$ & 11.1 & 6.8 \\
\hline (2E)-Hexenal & 848 & $846^{\mathrm{b}}$ & 20.8 & 5.3 \\
\hline 2-Etilhexanol & 1027 & $1030^{\mathrm{a}}$ & 13.3 & 18,1 \\
\hline Phenylacetaldehyde & 1043 & $1036^{\mathrm{b}}$ & $\operatorname{tr}$ & 1.8 \\
\hline$(E)$ - $\beta$-Ocimene & 1046 & $1044^{b}$ & 33.1 & 49.2 \\
\hline Naphthalene & 1182 & $1178^{\mathrm{b}}$ & 13.7 & 14.3 \\
\hline Eugenol & 1358 & $1356^{\mathrm{b}}$ & 3.2 & 2.7 \\
\hline \multicolumn{3}{|c|}{ Total } & 98.4 & 100.0 \\
\hline
\end{tabular}

$\mathrm{RI}_{\text {Calc }}=$ Calculated retention index; $\mathrm{RI}_{\mathrm{Lit}}=$ Literature retention index; tr: traces $(<0,05 \%)$; $a=$ FFNSC library [21]; ${ }^{b}=$ Adams library [20].

Table 5. Determination of the antioxidant capacity (DPPH radical scavenging and $\beta$-carotene / linoleic acid assays) and total phenolic compounds and total carotenoids in the natural and lyophilized pulps of Couepia bracteosa, on dry basis

\begin{tabular}{|c|c|c|}
\hline Description & Natural Pulp & Lyophilized Pulp \\
\hline DPPH (I\%) & $27.20 \pm 0.75^{\mathrm{b}}$ & $53.42 \pm 3.19^{\mathrm{a}}$ \\
\hline DPPH $\left(\mathrm{IC}_{50} \mathrm{mg} / \mathrm{ml}\right)$ & $8.8 \pm 0.34^{\mathrm{b}}$ & $2.08 \pm 0.12^{\mathrm{a}}$ \\
\hline$\beta$-carotene/linoleic acid $(\mathrm{I} \%)$ & $32.81 \pm 0.19^{\mathrm{b}}$ & $69.85 \pm 3.33^{\mathrm{a}}$ \\
\hline Total phenolic compounds $(\mathrm{mg} \mathrm{GAE} / 100 \mathrm{~g})$ & $124.53 \pm 12.98^{\mathrm{a}}$ & $117.44 \pm 2.7^{\mathrm{a}}$ \\
\hline Total carotenoids $(\mu \mathrm{g} \beta$-caroteneE/100g) & $1168.74 \pm 19.05^{\mathrm{b}}$ & $2898.76 \pm 41.41^{\mathrm{a}}$ \\
\hline
\end{tabular}

Results expressed as mean \pm standard deviation $(n=3)$. Means followed by the same letter in the columns do not differ significantly from each other by the Tukey test, at the probability level of $5 \%$. 
are close to that obtained from the açaí pulp (Euterpe oleracea Mart.): natural açaí, 31.9\%; lyophilized açaí, $76.1 \%$ [28].

The natural and lyophilized Pajurá pulps, on a dry basis, have shown low values for the total phenolic compounds (124.53 $\mathrm{mgGAE} / 100 \mathrm{~g}$ and $117.44 \mathrm{mgGAE} / 100 \mathrm{~g}$, respectively), very close to uvaia (Eugenia pyriformis Camb.) and cashew (Anacardium occidentale L.) (127 mgGAE/100 g and $118 \mathrm{mgGAE} / 100 \mathrm{~g}$, respectively), and relatively lower when compared with the value of açaí (454 mgEAG/100 g) [28]. Tannins, flavonoids, and phenolic acids make up a group of molecules derived from the secondary metabolism of plants, which are identified as phenolic compounds with high antioxidant power. More than 7,000 flavonoids have been identified in recent years and, due to the discovery of numerous pharmacological activities related to these compounds, the plants have been extensively studied to determine, quantify and discover new molecules and properties of the phenolic compounds [45]. Acacetin sulfate, oleuropein, and caffeic acid were found in the Pajurá pulp [6,7]. The moderate antioxidant activity observed for the Pajurá pulp, in the present study, could be attributed to these phenolic compounds, previously identified in the plant.

Carotenoids are known for their functional properties and significant antioxidant capacity, acting in the prevention of cardiovascular diseases and macular degeneration, such as provitamin A [46]. The natural and lyophilized Pajurá pulps are primary sources of carotenoids $(1168.74 \pm 19.05 \mathrm{mg} / 100 \mathrm{~g}$ and $2898.76 \pm 41.41 \mathrm{mg} / 100$ g, respectively), with similar content to the carotenoids present in açaí and acerola pulps $(2800 \pm 0.4 \mathrm{mg} / 100 \mathrm{~g}$ and $1400 \pm 0.1 \mathrm{mg} / 100 \mathrm{~g}$, respectively) [28]. It is very likely that the lyophilized pulp kept the bioactive compounds and the antioxidant activity of the in natural pulp, which confirms the lyophilization process as a useful technique in the conservation of perishable foods. The major carotenoids found in the Pajurá pulp were all-trans-neochrome and all-trans- $\beta$-carotene, with an approximate value of $43 \mu \mathrm{g}$ per g extract [6].

\section{Conclusion}

The Pajurá fruit stands out for its high content of total fibers, mainly insoluble fibers, that may be useful in the treatment of constipation and intestinal health. Also, it has potential as a functional food because it is a source of vitamin $\mathrm{C}$, total phenolic compounds, carotenoids and showed significant antioxidant activity. Additionally, it presents other excellent characteristics, with a good pulp yield, high sugar content, and low acidity, which are considered desirable aspects for appealing new fruits to the direct consumer and the food industry. The lyophilization process was efficient in the preservation of nutritional constituents and bioactive compounds, proving to be a useful tool that may offer an increase in the shelf life of these fruits, as well as their availability during the low season, with secure distribution to other different locations from the origin. Thus, as a poorly consumed and underutilized fruit, the Pajurá can contribute to the establishment of a more healthy and varied diet for the man, besides its contribution to increasing the productive chain and the sustainable development of the Amazon region.

\section{Acknowledgements}

The authors would like to thank CAPES and CNPq, the Brazilian Government's research funding agencies, for their financial support.

\section{References}

1. Vasco C, Ruales J, Kamal-Eldin A (2008) Total phenolic compounds and antioxidant capacities of major fruits from Ecuador. Food Chemistry 111: 816-823.
2. Neves LC, Tosin JC, Benedette RM, Cisneros-Zevallos L (2015) Post-harvest nutraceutical behaviour during ripening and senescence of 8 highly perishable fruit species from the Northern Brazilian Amazon region. Food Chemistry 174: 188-196.

3. Gordon A, Jungfer E, Silva BA, Maia JGS, Marx F (2011) Phenolic constituents and antioxidant capacity of four underutilized fruits from the Amazon Region. Journal of Agricultural and Food Chemistry 59: 7688-7699.

4. Falcão AM, Lleras E, Kerr WE (1981) Aspectos fenológicos, ecológicos e de produtividade do Pajurá (Couepia bracteosa Bentham) (Chrysobalanaceae). Acta Amazonica 11: 473-482.

5. Berto A, Silva AF, Visentainer JV, Mastsushita M, Fernandes E, Souza NE (2015) Proximate compositions, mineral contents and fatty acid compositions of native Amazonian fruits. Food Research International 77: 441-449.

6. Berto A, Ribeiro AB, Sentandreu E, de Souza NE, Mercadante AZ, Chisté RC, Fernandes E (2015) The seed of the Amazonian fruit Couepia bracteosa higher exhibits scavenging capacity against ROS and RNS than its shell and pulp extracts. Food Function DOI: 10.1039/c5fo00722d.

7. De Souza MP (2016) Caracterização química e avaliação do potencial antioxidante dos frutos mari-mari (Cassia leiandra), pajurá (Couepia bracteosa) e pitomba (Talisia esculenta). Doctoral thesis, Graduate Program in Chemistry, Universidade Federal do Amazonas, Manaus.

8. Spitzer V, Marx F, Maia JGS, Pfeilsticker K (1991) Identification of conjugated fatty acids in the seed oil of Acioa edulis Prance syn Couepia edulis (Chrysobalanaceae). JAOCS 68: 183-189.

9. Spitzer V, Marx F, Maia JGS, Pfeilsticker K (1991) Occurrence of conjugated fatty acids in the seed oil of Couepia longipendula (Chrysobalanaceae). JAOCS 68: 440-442.

10. Sanduja R, Alam M, Euler KL (1983) Constituents of Couepia paraensis. Journal of Natural Products 46: 149.

11. Jang DS, Park EJ, Kang Y-H, Vigo JS, Graham JG, Cabieses F, Fong HHS, Pezzuto JM, Kinghorn AD (2004) Phenolic compounds obtained from stems of Couepia ulei with the potential to induce quinone reductase. Archives of Pharmacal Research 27: 169-172.

12. Chaturvedula VSP, Gao Z, Hecht SM, Jones SH, Kingston DGI (2003) A new acetylated oleanane triterpenoid from Couepia polyandra that inhibits the lyase activity of DNA polymerase $\beta$. Journal of Natural Products 66: 1463-1465.

13. Genovese MI, Pinto MS, Gonçalves AESS, Lajolo FM (2008) Bioactive compounds and antioxidant capacity of exotic fruits and commercial frozen pulps from Brazil. Food Science and Technology International 17: 207- 214.

14. Marques LG, Silveira AM, Freire JT (2013) Drying characteristics of tropical fruits Drying Technology 24: 457-463.

15. Instituto Adolfo Lutz (2008) Métodos físico-químicos para análise de alimentos (4th ed.). Instituto Adolfo Lutz, São Paulo.

16. ANVISA - Agência Nacional de Vigilância Sanitária (2010) Farmacopeia Brasileira (5th ed.). Agência Nacional de Vigilância Sanitária, Brasília.

17. Laemmli UK (1970) Cleavage of structural proteins during the assembly of the head bacteriophage T4. Nature 227: 680-685.

18. Cunniff P, Association of Official Analytical Chemists (AOAC) (1995) Official methods of analysis of AOAC International. Association of Official Analytical Chemists, Washington.

19. Khan GR, Scheinmann F (1978) Some recent advances in physical methods for analysis and characterization of polyunsaturated fatty acids. Progress in the Chemistry of Fats and Other Lipids 15: 343-367.

20. Adams P (2007) Identification of essential oil components by gas chromatography / mass spectrometry (4th Ed.). Allured Publishing, Carol Stream.

21. Mondello L (2011) Flavors and fragrances of natural and synthetic compounds (2nd Ed). Wiley, New Jersey.

22. Likens ST, Nickerson GB (1964) Detection of certain hop oil constituents in brewing products. Journal of the American Society of Brewing Chemists 5-13.

23. Van Den Dool H, Kratz PDA (1963) Generalization of the retention index system including linear temperature programmed gas-liquid partition chromatography. Journal of Chromatography 11: 463-471.

24. Calderón de la Barca AM, Ochoa JL, Valencia ME (1985) Effect of the extraction of a hemagglutinin on the nutritive value of Amaranthus leocarpus seeds. Journal of Food Science 50: 1700-1702. 
25. Rodriguez-Amaya DB (2001) A guide to carotenoid analysis in foods. OMNI Research, Washington.

26. Singleton VL, Orthofer R, Lamuela-Raventus RM (1999) Analysis of total phenols and other oxidation substrates and antioxidants by means of Folin-Ciocalteu reagent. Methods in Enzymology 299: 152-178.

27. Miliauskas G, Venskutonis PR, Van Beek TA (2004) Screening of radical scavenging activity of some medicinal and aromatic plant extracts. Food Chemistry 85: 231-237.

28. Rufino MSM, Alves RE, Brito ES, Pérez-Jiménez J, Saura-Calixto F, Mancini-Filho JE (2010) Bioactive compounds and antioxidant capacities of 18 non-traditional tropical fruits from Brazil. Food Chemistry 121: 996-1002.

29. Carvalho JEU, Müller CH (2005) Biometria e rendimento percentual de polpa de frutas nativas da Amazônia. Comunicado Técnico No. 139, Embrapa Amazônia Oriental, Belém.

30. Al-Rabadi GJ, Torley PJ, Williams BA, Bryden WL, Gidley MJ (2012) Particle size heterogeneity in milled barley and sorghum grains: Effects on physico-chemical properties and starch digestibility. Journal of Cereal Science 56: 396-403.

31. NEPA-Núcleo de Estudos e Pesquisas em Alimentação (2011) Tabela Brasileira de Composição de Alimentos (4th ed.). Universidade Estadual de Campinas, Campinas.

32. Food and Nutrition Board, Institute of Medicine, National Academies (2000) Dietary Reference Intakes (DRIs): Estimated Average Requirements. https://www.nal.usda.gov/ sites/default/files/fnic_uploads//recommended_intakes_individuals.pdf. Accessed Dec 2017.

33. ANVISA - Agência Nacional de Vigilância Sanitária (2016) Alimentos com alegações de propriedades funcionais e de saúde. http://portal.anvisa.gov.br/alimentos/alegacoes. Accessed Dec 2017

34. Brazilian Food Composition Table, www.fcf.usp.br/tbca. Accessed Dec 2017.

35. Elleuch M, Bedigian D, Roiseux O, Besbes S, Blecker C, Atti H (2011) Dietary fiber and fiber-rich byproducts of food processing: Characterisation, technological functionality and commercial applications: A review. Food Chemistry 124: 411-421.

36. Lim W, Gan M, Ong M, Chew CH (2015) Lauric acid abolishes interferon-gamma (IFN $\sim$ )-induction of intercellular adhesion molecule-1 (VCAM-1) and vascular cell adhesion molecule-1 (VCAM-1) expression in human macrophages. Asian Pacific Journal of Reproduction 4: 217-221.
37. Schwingshack1, L., \& Hoffmann, G. (2014). Monounsaturated fatty acids, olive oil and health status: a systematic review and meta-analysis of cohort studies. Lipids in Health Disease 13: 154-169.

38. Oliveira AL, Lopes RB, Cabral F, Berlin MN (2006) Volatile compounds from pitanga (Eugenia uniflora L.) Food Chemistry 99: 1-5.

39. Chyau C-C, Chen S-Y, Wu C-M (1992) Differences of volatile and nonvolatile constituents between mature and ripe guava (Psidium guajava L.) fruits. Journal of Agricultural and Food Chemistry 40: 845-849.

40. Stefanello MEA, de Mello-Silva R (2002) Volatile constituents of Talauma ovata A. St.-Hil. Fruits. Journal of Essential Oil Research 17: 455-456.

41. Aguiar MCS, Silvério FO, Pinho GP, Lopes SN, Fidêncio PH, Ventura SJ (2014) Volatile compounds from fruits of Butia capitata at different stages of maturity and storage. Food Research International 62: 1095-1099.

42. Franco MRB, Shibamoto T (2000) Volatile composition of some brazilian fruits umbu-caja (Spondias citherea), camu-camu (Myrciaria dubia), araçá-boi (Eugenia stipitata), and cupuaçu (Theobroma grandiflorum). Journal of Agricultural and Food Chemistry 48: 1263-1265.

43. Van Bull VJ, Brouns FJPH (2014) Health effects of wheat lectins: a review. Journal of Cereal Science 59: 112-117.

44. Naik GH, Priyadarsini KI, Satav JG, Banavalikar MM, Sohoni PP, Biyani K, Mohan $\mathrm{H}$ (2003) Comparative antioxidant activity of individual herbal components used in Ayurvedic medicine. Phytochemistry 63: 97-104.

45. Villiers A, Venter P, Pasch H (2016) Recent advances and trends in the liquidchromatography-mass spectrometry analysis of flavonoids. Journal of Chromatography A 1430: 16-78.

46. Murilo E, Giuffrida D, Menchaca D, Dugo P, Torre G, Meléndez-Martinez AJ, Mondello L (2012) Native carotenoids composition of some tropical fruits. Food Chemistry 140: 825-836.

Copyright: (C2018 Massing LT. This is an open-access article distributed under the terms of the Creative Commons Attribution License, which permits unrestricted use, distribution, and reproduction in any medium, provided the original author and source are credited. 